\title{
THE EFFECTIVENESS OF OTTER APPLICATION IN IMPROVING ENGLISH FRESHMEN'S PRONUNCIATION AT SCHOOL OF FOREIGN LANGUAGES - THAI NGUYEN UNIVERSITY
}

Duong Hong Yen*, Pham Mai Linh

TNU - School of Foreign Languages

\begin{tabular}{|c|c|c|}
\hline \multicolumn{2}{|c|}{ ARTICLE INFO } & ABSTRACT \\
\hline Received: & $01 / 3 / 2021$ & This study was conducted as a quasi-experimental study with the \\
\hline Revised: & $25 / 3 / 2021$ & $\begin{array}{l}\text { purposes of evaluating the effectiveness of Otter application as a tool } \\
\text { for pronunciation practice in order to improve students' pronunciation }\end{array}$ \\
\hline Published: & $26 / 3 / 2021$ & $\begin{array}{l}\text { in particular and their speaking performance in general; examining how } \\
\text { it benefits students and should it be recommended for being used }\end{array}$ \\
\hline \multicolumn{2}{|l|}{ KEYWORDS } & widely outside of the classroom. The subjects of the study were forty \\
\hline \multicolumn{2}{|l|}{ Otter application } & Languages, Thai Nguyen University. To collect the data, questionnaire, \\
\hline \multicolumn{2}{|l|}{ Mobile application } & $\begin{array}{l}\text { tests and interviews were used. The results suggested that this } \\
\text { application would make a great contribution to students' pronunciation }\end{array}$ \\
\hline \multicolumn{2}{|l|}{ Teaching speaking } & improvement if it was employed for supplementary practice. It can be \\
\hline \multicolumn{2}{|c|}{ Teaching pronunciation } & $\begin{array}{l}\text { concluded that the implementation of supplementary practices with } \\
\text { Otter in learning process has beneficial effects on students' speaking }\end{array}$ \\
\hline \multicolumn{2}{|l|}{ Self-learning } & pecially in pronunciation. \\
\hline
\end{tabular}

\section{HIỆU QUẢ CỦA ÚNG DỤNG OTTER TRONG VIỆC NÂNG CAO KHẢ NĂNG PHÁT ÂM CỦA SINH VIÊN NĂM THÚ̉ NHẤT TRƯỜNG NGOẠI NGŨ - ĐẠI HỌC THÁI NGUYÊN}

\section{Dương Hồng Yến*, Phạm Mai Linh}

Truờng Ngoại ngũ - ĐH Thái Nguyên

\begin{tabular}{|c|c|c|}
\hline \multicolumn{2}{|c|}{ THÔNG TIN BÀI BÁO } & \multirow{2}{*}{$\begin{array}{l}\text { TÓM TÁT } \\
\text { Bài báo này là một nghiên cứu bán thực nghiệm nhằm mục đích đánh }\end{array}$} \\
\hline Ngày nhận bài: & $01 / 3 / 2021$ & \\
\hline Ngày hoàn thiện: & $25 / 3 / 2021$ & ực hănh \\
\hline TÙ' KHÓA & $26 / 3 / 2021$ & $\begin{array}{l}\text { chung cho sinh viên; đánh giá những lợi ích của ứng dụng và đưa ra } \\
\text { kết luận có nên sử dụng ứng dụng nây để làm công cụ cho sinh viên } \\
\text { tự thực hành ngoài lớp học hay không. Đối tượng nghiên cứu là } 40\end{array}$ \\
\hline & \\
\hline \multicolumn{2}{|l|}{ Úng dụng di động } & \\
\hline \multicolumn{2}{|l|}{ Dạy kỹ năng nói } & kết luận rằng \\
\hline \multicolumn{2}{|l|}{ Dạy phát âm } & $\begin{array}{l}\text { ác bài tập bổ trợ với ứng dụng Otter trong quá trình } \\
\text { ông tích cực đên kỹ năng nói của sinh viên, đăc biêt }\end{array}$ \\
\hline ự học & & \\
\hline
\end{tabular}

DOI: https://doi.org/10.34238/tnu-jst.4062

* Corresponding author. Email: yendh@tnu.edu.vn 


\section{Introduction}

It is noticeable that pronunciation is one of the main criteria in most of English speaking test rating scales, for example: IELTS speaking test (fluency and coherence, lexical resource, grammatical range and accuracy, pronunciation) [1]; VSTEP (grammar, vocabulary, pronunciation, fluency, discourse management) [2]; FCE (grammar and vocabulary, discourse management, pronunciation, interactive communication) [3]. Therefore, it cannot be denied that understandable pronunciation is one of the key requirements for learners' language proficiency and it has certain effect on learners' speaking performance in general. According to Seidlhofer [4], pronunciation plays a significant role in real-life communication as it reflects the speakers' identities and the communities which they belong to. Good pronunciation also helps students get better academic achievements. However, Vietnamese students' pronunciation errors are still an issue of concern [5]. Furthermore, a study by Abbas Pourhosein Gilakjani [6] stated that pronunciation is an integral part of foreign language learning since it directly affects learners' communicative competence as well as performance. Limited pronunciation skills can decrease learners' self-confidence, restrict social interactions, and negatively affect estimations of a speaker's credibility and abilities. This situation can be seen when students rarely actively speak English inside classrooms and in daily life due to the fear of making pronunciation mistakes. Dealing with these problems, the use of technology for self-practice under the instruction and controlment of teachers can be an effective way to help students improve their speaking pronunciation. According to $\mathrm{Li}$ [7], the integration of app in learning increases students' motivation and learning performance. Sharing the same concern, Haraydi \& Aprianoto [8] stated that it becomes extremely necessary to provide a technologically-based learning tool, a Mobile Assisted Language learning, which lecturers and students can easily access with low cost, which possesses simple operation manual, and which fits into the learning needs of digitized students, but contains the material needed for the achievement of learning goals. A lot of studies have been conducted to review and investigate the impacts of mobile apps and technology resources on improving students' pronunciation. Fouz [9] reviewed some of the most important mobile apps available for learning pronunciation. Yolanda Joy CalvoBenzies [10] also reviewed a number of existing programs and other materials specifically designed to improve learner pronunciation by classifying them into three main categories: tool for tuition, tools for listening, tools for recording. PenkhaeWongsuriya [11] showed that leaners can use Google translate application to listen to some difficult words and improve their pronunciation accordingly. A number of mobile applications were introduced and proved to be beneficial for students' pronunciation improvement in the previous studies; however, not many of them allow learners to use custom materials and integrate what they learn in class or in other subjects/skills to their pronunciation practice. This paper, therefore, intends to be the first approach to filling this gap. Otter is not an English pronunciation app., it is an application which turns speaker voice into notes. In other words, students will practice their pronunciation by writing notes with their voice. This way, they can learn and test their pronunciation at the same time as they will have time to replay what they listen to and if a word is pronounced incorrectly, they will receive an incorrect word in their notes. The study aimed at answering two questions:

1. What is the current status of students' pronunciation self-practice at School of Foreign Languages, Thai Nguyen University?

2. What are the effects and benefits of the application of Otter to students' pronunciation?

\section{Methodology}

The participants of this study were 40 first-year students from an English oral proficiency class at School of Foreign Languages, Thai Nguyen University. Their English proficiency ranged from A2 to B1 (based on the Common Vietnamese Framework of Reference). In selecting the 
participants, the researcher used purposive sampling technique, which according to Patton [12], is a technique widely used in qualitative research to identify and select information rich cases for the most effective use of limited resources.

Table 1. The scoring rubric of pronunciation adapted from VSTEP speaking rating scale

\begin{tabular}{|c|c|}
\hline Rating scale & Description \\
\hline 0 & Test-taker is not present. \\
\hline 1 & Performance does not satisfy Band 2 descriptors \\
\hline 2 & $\begin{array}{l}\text { Test-taker is often unintelligible } \\
\text { Test-taker can articulate a very limited repertoire of learnt words and phrases with } \\
\text { limited accuracy }\end{array}$ \\
\hline 3 & $\begin{array}{l}\text { Test-taker is mostly intelligible } \\
\text { Test-taker can articulate simple words and phrases but conversational partners will } \\
\text { need to ask for repetition from time to time }\end{array}$ \\
\hline 4 & $\begin{array}{l}\text { Test-taker is mostly intelligible and has acquired a quite clear pronunciation } \\
\text { Test-taker makes some errors with individual sounds } \\
\text { Test-taker shows some efforts in word stress despite frequent mispronunciations }\end{array}$ \\
\hline 5 & $\begin{array}{l}\text { Test-taker is mostly intelligible and has acquired a quite clear pronunciation } \\
\text { Test-taker makes occasional errors with individual sounds } \\
\text { Test-taker shows efforts in word stress despite some mispronunciations }\end{array}$ \\
\hline 6 & $\begin{array}{l}\text { Test-taker is intelligible and has acquired a quite clear and natural pronunciation } \\
\text { Test-taker generally clearly articulates individual sounds } \\
\text { Test-taker generally places word stress, but does not show efforts with sentence stress } \\
\text { Test-taker shows few efforts with intonation }\end{array}$ \\
\hline 7 & $\begin{array}{l}\text { Test-taker is intelligible and has acquired a clear and natural pronunciation } \\
\text { Test-taker generally clearly articulates individual sounds } \\
\text { Test-taker generally places word stress and shows efforts with sentence stress despite } \\
\text { rather low accuracy } \\
\text { Test-taker shows some efforts with intonation }\end{array}$ \\
\hline 8 & $\begin{array}{l}\text { Test-taker is intelligible and has acquired a very clear and natural pronunciation } \\
\text { Test-taker clearly articulates individual sounds } \\
\text { Test-taker generally places word and sentence stress } \\
\text { Test-taker shows good efforts with intonation }\end{array}$ \\
\hline 9 & $\begin{array}{l}\text { Test-taker is intelligible with individual sounds clearly articulated, sentence and word } \\
\text { stress accurately placed } \\
\text { Test-taker has appropriate intonation } \\
\text { Test-taker places sentence stress flexibly and correctly to express different meanings }\end{array}$ \\
\hline 10 & $\begin{array}{l}\text { Test-taker is intelligible with individual sounds clearly articulated, sentence and word } \\
\text { stress accurately placed } \\
\text { Test-taker has appropriate intonation } \\
\text { Test-taker varies intonation and places sentence stress correctly to express different } \\
\text { meanings and intended functions }\end{array}$ \\
\hline
\end{tabular}

The study was conducted in the second semester (lasted for 15 weeks) of the students' first school year when they have studied Pronunciation practice in the first semester, which ensures that students have already had basic knowledge and exposure to English pronunciation rules and features. Firstly, the researcher introduced the application to the students and gave them instructions to use it properly and effectively. Then, an audio and its script were given to the students on a weekly basis for practice. The total of 15 listening audios and scripts were given to the students in 15 weeks of the semester. All of them are from students' Oral Proficiency textbook, which were used for listening practice inside classroom. The students had to read after the voice record with the reference of the script while listening to the audio carefully, then they will read the script out loud to Otter, which would transfer their voice into words. If there was a 
mistake, students could pause their recording, deleted the incorrect word and read it again. Finally, they were asked to share their most satisfied note on Otter to the researcher. Data for the present study were collected by means of a questionnaire, three tests and a set of interview questions. The combination of the three approaches ensures careful insight into the research because the results of the three techniques can be supportive of each other. There was one questionnaire, which comprised 11 both open- ended and close- ended questions. It was applied at the beginning of the study to explore the current status of students' pronunciation practice at School of Foreign Languages, Thai Nguyen University. The questionnaire was delivered directly to 130 students, whose current course was English Oral Intermediate (EOI); semester 2, group N04, N06, N07. The questionnaire was written in English because the participants were English major students. However, to be appropriate for the freshmen's proficiency and achieve the maximum effect, the language used was comparatively understandable, concise and relevant. Interview is the second main instrument used in the research to gather opinions and suggestions of students. A small interview was conducted at the end of the study with the purpose of exploring students' evaluation of Otter, how their pronunciation has improved by practicing with the application. Both close-ended and open-ended questions were employed so that the researcher could collect the most positive answers as well as deeply discover the thought of respondents. Test is the third main instrument to measure the level of students before and after the experimental class started. The tests consist of a pre-test conducted in week 1 and two post-tests applied in week 7 and week 15. In order to assess students' pronunciation, the scoring rubric of pronunciation adapted from VSTEP speaking rating scale (table 1) was used.

\section{Findings and discussion}

\subsection{Findings from the questionnaire}

\subsubsection{Students' awareness of the importance of English pronunciation}

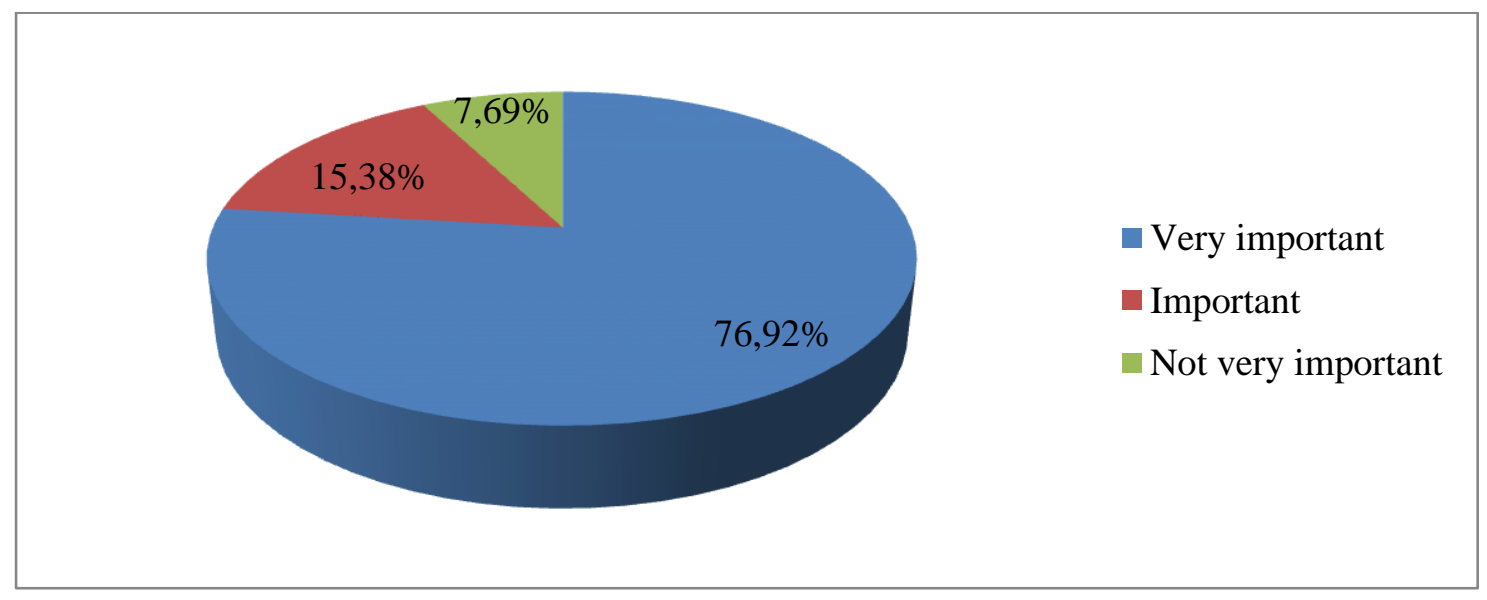

Figure 1. Students' awareness of the importance of English pronunciation

The data from Figure 1 indicates that the majority of students are well aware of the importance of pronunciation with over $76 \%$ and $15 \%$ chose that it is "very important" and "important" relatively. However, there are still a small number of students (more than 7\%) have not realized that pronunciation plays an essential role in their language proficiency as they considered that it is not very important. 


\subsubsection{Students' frequency of practicing pronunciation}

In order to develop any language skills, regular practice holds the main key to success. However, only about more than $18 \%$ of the students spend time practicing their pronunciation frequently at home. The proportion of students who do not practice frequently is comparatively high. Especially, more than $20 \%$ of them rarely or never practice at all.

\subsubsection{Students' learning tools}

As entering the university, almost all students are equipped with high-tech devices such as laptop, smartphone, Ipad, and so on, to help them in the study process. Among these devices, laptop is the most popular one. It is also the device that enables students to use a lot of services with the most convenience. Besides, some students make use of both laptop and smartphone or Ipad as these later tools provide them with more mobile usage.

\subsubsection{Problems encountered by students while practicing pronunciation}

When it comes to the difficulties that students have while they practice pronunciation, all the participants claim that they often find themselves in troubles when choosing suitable materials for pronunciation practice and checking whether their pronunciation is correct.

\subsection{Findings from the tests: pre-test and post-tests}

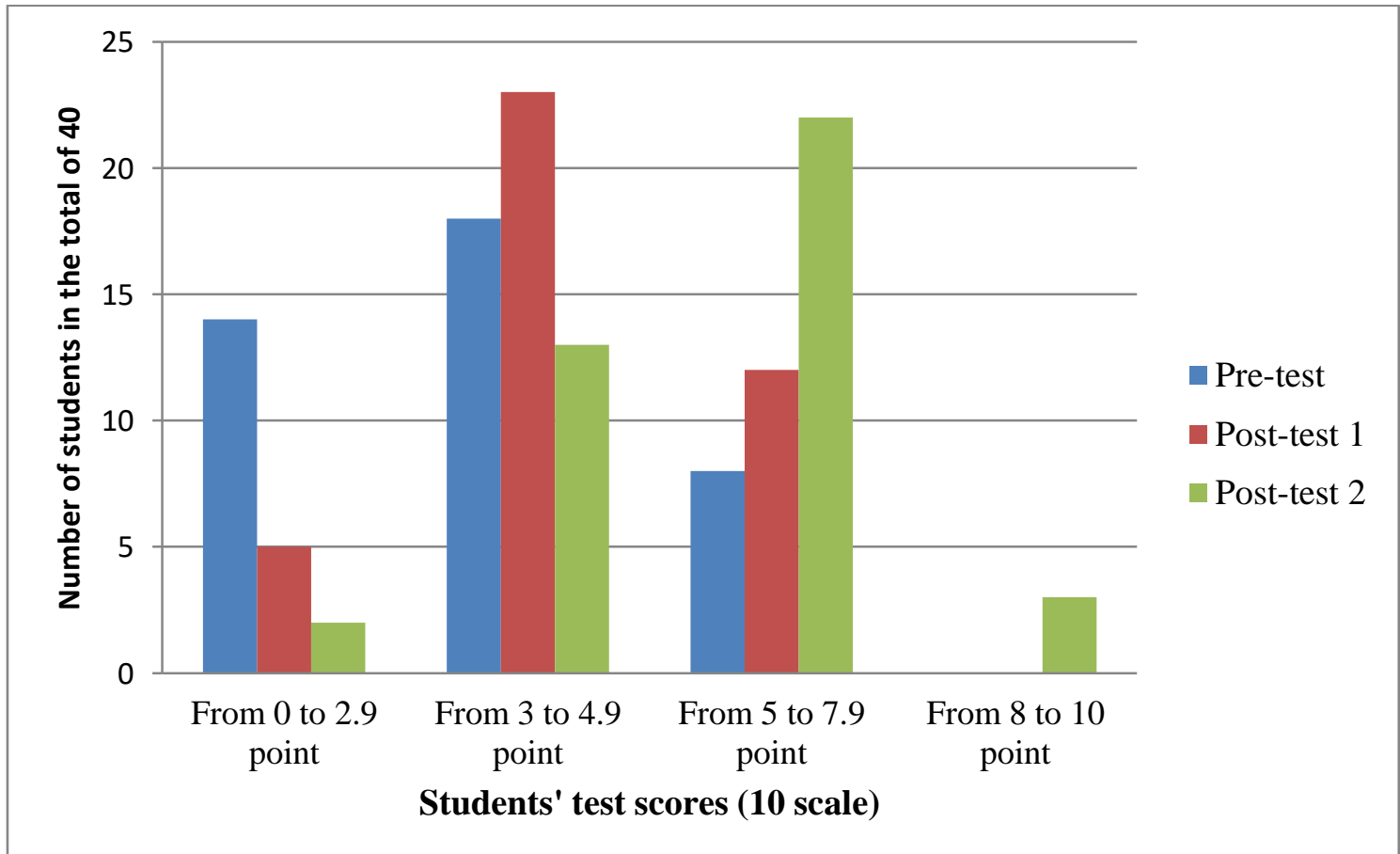

Figure 2. The test scores of the experimental group

As shown in Figure 2, the pre-test results of the experimental group were extremely low. 32 out of 40 students scored under 5 point, 14 of whom scored under 3 . The number of students getting 5 to 7.9 points was very small, accounting for just $20 \%$ of the total. In addition, none of those students got from 8 to 10 points. It can be said that the pronunciation skill of freshmen was alarmingly weak. Results from post-test 1 indicated that although the average marks of the whole group were still low when there was no good mark (from 8 to 10 point) and the majority of students' scores was under 5 points, a better improvement could be seen. The number of students 
scored under 3 point decreased significantly from 14 to 5 students while there was an increase in the number of students scored from 5 to 7.9 (4 students, which equal to $10 \%$ ). This provided the evidence that the application of Otter might be effective. To be more convincible, post- test 2 was undertaken after post-test 1 eight weeks. The test results also pointed out the progress of students in the experimental group after a few weeks. More than a half of the students scored above 5 points, in which there were three students got good marks (from 8 to 10). Comparing to the pretest's score, this figure experienced a tremendous rise of $42.5 \%$. Besides, the number of students scored below 3 dropped to 2 students, which in comparison to the pre-test's score decreased by $30 \%$. In brief, by comparing the result of the pre-test and the post-test 2 , it was clear that a huge progress in the pronunciation skill of students was achieved.

\subsection{Findings from the interview}

Together with the test scores, the results from the interview contribute to ensure the utility and objectiveness of the application evaluation. The objects of the interview were 10 students randomly selected within the group. From the responses of the respondents, all of them considered Otter as a good tool to practice pronunciation as well as their speaking skill. The use of Otter received the optimistic responses and appreciations from the respondents. Otter was convinced to be one of the valuable and useful applications for practicing extensive listening.

\subsection{Discussion}

To sum up, the results of the research, reported by the questionnaire, the test scores, and the interview, fully answer the two research questions. The questionnaire, pre-test and post- tests and the interview employed to reach the conclusion, are in an interactive relationship. The findings of the questionnaire offer a solid foundation orienting for the discovery of appropriate application used in the experiment. The test results directly reflect the significant improvement of participants during 15 weeks involved in the experimental group. In addition, the interview contributes to confirm the positive effect of the Otter application by investigating participants' opinions toward the application used. The results of the interview support the conclusion that students could benefit a lot from the Otter employment.

\section{Conclusion}

In conclusion, Otter is proved to have a great impact on students' pronunciation in different ways. This application would make a great contribution to students' pronunciation skills as well as speaking skills development if it is employed for supplementary practice. It is hoped that this research will stimulate consideration of employing Otter both inside and outside of the classroom to better support students in foreign language learning process. The findings of the study imply that teachers and educators should motivate students to take use of the advantages of technology both inside and outside classroom. According to Hammer [13], teachers should pay attention to foster students learning motivation from which their love for learning could be developed, accordingly they will feel more enjoyable instead of considering it a compulsory and tiring task. Therefore, recommending and offering students new sources with the advantages of technological support in order to reduce the unnecessary problems they may have in the learning process is one of the ways to bring more inspiration, motivation and encouragement to students.

\section{REFERENCES}

[1] IDP IELTS, "IELTS speaking band descriptors." [Online]. Available: https://www.ielts.com/about/news-and-articles/article-understanding-the-ielts-speaking-banddescriptors . [Accessed Oct. 23, 2020].

[2] British Council, "VSTEP speaking 3-5 rating scale." [Online]. Available: https://www.britishcouncil.vn/sites/default/files/new_directions_2016_nathan_carr_systematic_support _for_a_communicative_standardized_proficiency_test_in_vietnam.pdf. [Accessed Oct. 23, 2020]. 
[3] Cambridge English, “Assessing speaking performance - Level B2.” [Online]. Available: https://www.cambridgeenglish.org/images/168619-assessing-speaking-performance-at-level-b2.pdf. [Accessed Oct. 23, 2020].

[4] B. Seidlhofer, "Closing a Conceptual Gap: The Case for a Description of English as a Lingua Franca," International Journal of Applied Linguistics, vol.11, no.2, pp. 133-158, 2001.

[5] A. Graceffo, "Teaching English Pronunciation to Vietnamese Students," Foreign Policy Journal, vol.8, no.2, pp.112-121, 2010.

[6] A. P. Gilakjani, "A study of factors affecting EFL learners' English pronunciation learning and strategies for instruction," International journal of Humanities and Social Science, vol. 2, no. 3, pp.155-165, February 2012.

[7] K. C. Li, L. Y.-K. Lee, S.-L. Wong, I. S.-Y. Yau, and B. T.-M Wong, "Effects of mobile apps for nursing students: learning motivation, social interaction and study performance," Open Learning: The Journal of Open, Distance and e-Learning, vol. 33, no.2, pp. 99-114, 2018.

[8] S. Haryadi, and Aprianoto, "Integrating "English pronunciation" app into pronunciation teaching: How it affects students' participation and learning," JOLLT Journal of Languages and Language Teaching, vol. 8, no.2, pp. 202-212, 2020, doi: 10.33394/jollt.v8i2.2551.

[9] J. Fouz, "Can Apple's iPhone Help to Improve English pronunciation Autonomously?" in CALL: Using, Learning, Knowing, EUROCALL Conference Proceedings, S. Bradley and S. Thouesny, Eds. Dublin: Researchpublishing.net, 2012, pp. 81-87.

[10] C. Benzies, and Y. Joy, "Contributions of New Technologies to the Teaching of English Pronunciation," Language Value, vol. 9, no. 1, pp. 1-35, 2017, doi: 10.6035/LanguageV.2017.9.2.

[11] P. Wongsuriya, "Improving the Thai students' ability in English pronunciation through mobile application,” Academic Journal, vol. 15, no. 4, pp. 175-185, April 2020.

[12] M. Q. Patton, Qualitative Research and Evaluation Methods, 3rd ed. Thousand Oaks, CA: Sage Publications, 2002.

[13] J. Harmer, The Practice of English Language Teaching, 3rd ed. Harlow: Longman, 2001. 